\title{
PROSES PENGAJUAN MURABAHAH \\ PADA BANK SYARIAH RAJASA KANTOR KAS KALIREJO LAMPUNG TENGAH
}

\author{
Dina Ani Fatima \\ D3 Perbankan Syariah IAIN METRO \\ Fatimahdina2202@gmail.com \\ Selvia Nuriasari \\ S1 Perbankan Syariah IAIN METRO \\ selviasari7@gmail.com
}

\author{
Diterima: Oktober $2019 \quad$ Direvisi : November 2019
}

Diterbitkan: November 2019

\begin{abstract}
Murabaha financing at Bank Syariah Rajasa is fulfill to consumptive and productive needs. In submission of murabahah financing, the prospective customers submits through a process determined by the Bank Syariah Rajasa. In the submission process, Bank Syariah Rajasa must comply with OJK standart (Standar Produk Perbankan Syariah Murabahah tabun 2016. The purpose of thie research is to see match between standart Bank Syariah Rajasa with the Standart OJK. This type of research is a fied research ocated at Bank Syariah Rajasa Kalirejo Central lampung Cash Office, which is descriptive quaitative, with primary data sources are Account Afficers, Teers and Finance Staff administrative at BPRS Rajasa Kalirejo Central lampung Cash Office. Based on the results in the field it was colcluded that the process of distributing murabahah financing in Bank Syariah Rajasa have four process, according to the OJK standard, however, there was a gap between the practice and the standards of the OJK, the third stage or process regarding the approval of the financing proposal by the bank. OJK standards are mentioned to confirm approval of submission of murabahah financing in the form of a principle approval letter, while Bank Syariah Rajasa notifies prospective customers by telephone without giving a principle approval letter of offering letter

Keyword: submission murabahab financing, OJK standard
\end{abstract}

Abstrak

Pembiayaan murabahah di Bank Syariah Rajasa disalurkan untuk memenuhi kebutuhan konsumtif ataupun produktif masyarakat. Dalam pengajuan pembiayaan murabahah, calon nasabah melakukan pengajuan pembiayaan dengan melalui proses yang ditetapkan di Bank syariah Rajasa. Dalam proses pengajuan Bank Syariah Rajasa harus mematuhi Standar Produk Perbankan Syariah Murabahah tahun 2016 yang ditetapkan OJK. Maka tujuan penelitian ini untuk melihat kesesuaian proses pengajuan pembiayaan murabahah dengan Standar Produk Perbankan Syariah Murabahah tahun 2016. Jenis penelitian ini adalah penelitian lapangan (field research) yang berlokasi di Bank Syariah Rajasa Kantor Kas Kalirejo Lampung Tengah, yang bersifat deskriptif kualitatif, dengan sumber data primer adalah Account Officer, Teller dan staf administrasi bagian pembiayaan di BPRS Rajasa Bandar Jaya Lampung Tengah. Berdasarkan hasil di lapangan, disimpulkan bahwa proses penyaluran pembiayaan murabahah pada Bank Syariah Rajasa Kantor Kas Kalirejo melalui empat tahap,sesuai standar OJK, tetapi, ada kesenjangan antara praktik dengan standar dari OJK yaitu pada tahap ketiga mengenai persetujuan pengajuan pembiayaan oleh pihak bank.Standar OJK disebutkan untuk mengkonfirmasi persetujuan pengajuan pembiayaan murabahah dalam bentuk surat persetujuan prinsip atau Offering Letter, sedangkan Bank Syariah Rajasa melakukan pemberitahuan ke calon nasabah melalui telepon tanpa memberikan surat persetujuan prinsip atau Offering Letter.

Kata kunci : pengajuan pembiayaan murabahah, Standar OJK

\section{A. Latar Belakang}

Produk pembiayaan murababah Bank Syariah Rajasa Kantor Kas Kalirejo merupakan jenis pembiayaan murabahah yang cukup banyak nasabahnya, yaitu sebanyak $55 \%$ dari total nasabah, ha ini berdasarkan ahsi wawancara dengan Ahmad Khusaeni seaku AO. 
Mengenai data pasti tentang pertumbuhan produk ini, peneliti tidak dapat memperolehnya dikarenakan data rahasia bank. ${ }^{1}$ Murabahah sendiri memiliki arti sebagai akad jual beli atas barang tertentu dimana penjual menyebutkan dengan jelas barang yang diperjual belikan termasuk harga pembelian barang kepada pembeli kemudian ia mensyaratkan keuntungan dalam jumlah tertentu. ${ }^{2}$

Berdasarkan buku "Standar Produk Perbankan Syariah Murabahab" yang dikeluarkan OJK pada tahun 2016, bahwa proses pengajuan pembiayaan murabahah pada perbankan syariah harus melalui empat (4) tahap pengajuan pembiayaan murabahah yaitu: tahap pertama, Pengajuan Pembiayaan; tahap kedua, Verifikasi Dokumen Calon Nasabah; tahap ketiga, persetujuan pengajuan pembiayaan yang didalamnya juga berisi pemberitahuan persetujuan pengajuan pembiayaan; dan tahap keempat, pengikatan pembiayaan dan pengikatan jaminan. ${ }^{3}$ Proses pengajuan pembiayaan murabahah tersebut merupakan bagian dari SOP murabahah yang harus diikuti dan dipatuhi oleh pihak bank.

Keberadaan standar produk ini bertujuan membantu para pelaku industri perbankan syariah dalam memanfaatkan produk berbasis akad Murabahah secara optimal tanpa mengesampingkan kepatuhan operasionalisasi produk pada ketentuan dan standar syariah yang berlaku. Operasionalisasi produk yang patuh pada ketentuan dan standar syariah diharapkan dapat meningkatkan daya saing produk perbankan syariah sehingga mampu memberikan manfaat dan pelayanan yang lebih baik bagi para nasabah maupun calon nasabah. ${ }^{4}$

Berdasarkan permasalahan diatas, peneliti tertarik untuk meneliti dengan tujuan untuk mengetahui kesesuaian proses pengajuan pembiayaan murabahah pada Bank Syariah Rajasa Kantor Kas Kalirejo Lampung Tengah ditinjau dari Standar Produk Murabahah OJK.

${ }^{1}$ Ahmad Khusaeri (AO), Wawancara Pribadi, 6 Juli 2019

Muhammad, Sistem dan Prosedur Operasional Bank Syariah, (Yogyakarta: UII Press, 2008), h. 103

3 OJK, Standar Produk Pembiayaan Murabahah,

https://www.ojk.go.id/id/kanal/syariah/berita-dan-kegiatan/publikasi/Pages/BukuStandar-Produk-Perbankan-Syariah-Murabahah.aspx

${ }^{4}$ ibid 


\section{B. KERANGKA TEORI}

Berdasarkan standar produk pembiayaan murabahabyang dikeluarkan OJK tahun 2016, murabahah adalah akad transaksi muamalah dengan menerapkan prinsip jual beli barang sebesar harga perolehan barang ditambah margin yang disepakati oleh para pihak. Harga perolehan diinformasikan oleh penjual kepada pembeli. ${ }^{5}$

Berdasarkan Fatwa Dewan Syariah Nasional (DSN) Majelis Ulama Indonesia NO: 111/DSN-MUI/IX/2017 tentang akad jual beli Murabahah, menerangkan bahwa Akad bai' al-murabahah adalah akad jual beli suatu barang dengan menegaskan harga belinya kepada pembeli dan pembeli membayarnya dengan harga yang lebih sebagai laba ${ }^{6}$.

Peraturan Bank Indonesia Nomor: 7/46/PBI/2005 mengatakan bahwa Murabahah adalah jual beli barang sebesar harga pokok barang ditambah dengan margin keuntungan yang disepakati.

Pengertian murabahah juga disebutkan dalam Buku Standar Produk Murababah yang menyebutkan bahwa murabahah adalah Akad transaksi muamalah dengan menerapkan prinsip jual beli barang sebesar harga perolehan barang ditambah margin yang disepakati oleh para pihak. Harga perolehan diinformasikan oleh penjual kepada pembeli. ${ }^{8}$

Berdasarkan pengertian di atas, maka di atas dapat disimpulkan bahwa murabahah merupakan akad jual beli dimana Bank akan membeli barang kebutuhan nasabah dan menjualnya kembali kepada nasabah dengan tambahan keuntungan (margin).

Adapun rukun, syarat dan ketentuan murabahah akan dijelaskan dibawah ini yaitu sebagai berikut:

a. Rukun dan Syarat Murabahab ${ }^{9}$

1) Pihak yang berakad (Al-'aqidain)
a) Penjual (Bank)
b) Pembeli (Nasabah)
c) Pemasok (Supplier)

\footnotetext{
5 Standar Produk Pembiayaan Murabahah, alamat : https://www.ojk.go.id/id/kanal/syariah/berita-dan-kegiatan/publikasi/Pages/BukuStandar-Produk-Perbankan-Syariah-Murabahah.aspx

6 Fatwa DSN-MUI No: 111/DSN-MUI/IX/2017 Tentang Akad Jual Beli Murabahah

7 Peraturan Bank Indonesia (PBI) Nomor: 7/46/PBI/2005 Tentang Akad Penghimpunan dan Penyaluran Dana Bagi Bank yang Melaksanakan Kegiatan Usaha Berdasarkan Prinsip Syariah

8 Buku Standar Produk Murabahah, https://www.ojk.go.id/id/kanal/syariah/berita-dankegiatan/publikasi/Pages/Buku-Standar-Produk-Perbankan-Syariah-Murabahah.aspx

9 Buku Standar Produk Murabahah...
} 
2) Obyek yang diakadkan (Mahallul 'Aqad)

a) Adanya wujud barang yang diperjualbelikan

b) Harga barang

3) Tujuan Akad (Maudhu'ul Aqad)

4) Akad (Sighat al-'Aqad)

a) Serah (ijab)

b) Terima (qabul)

b. Ketentuan Berdasarkan Fatwa DSN MUI No. 4 tahun $2000{ }^{10}$ :

1) menetapkan tentang ketentuan murabahah pada Bank Syariah yaitu sebagai berikut:

a) Bank dan nasabah dalam melakukan akad harus terbebas dari riba.

b) Barang yang diperjual belikan harus halal.

c) Bank membiayai sebagian atau seluruh harga barang yang telah disepakati spesifikasinya

d) Bank membeli barang yang diperlukan nasabah atas nama bank, dan pembelian harus sah dan bebas riba.

e) Bank harus menyampaikan semua hal yang berkaitan dengan pembelian barang, misalnya pembelian dengan cara utang.

f) Bank kemudian menjual barang tersebut kepada nasabah (pemesan) dengan harga jual sama dengan harga beli ditambah dengan keutungan dengan memberitahu secara jujur harga pokok kepada nasabah dan biaya-biaya lainnya.

g) Nasabah membayar dengan harga yang disepakati dan jangka waktu yang telah disepakati antara Bank dan nasabah.

h) Untuk menghindari penyalahgunaan akad pihak Bank dapat mengadakan perjanjian khusus dengan nasabah. Jika bank hendak mewakilkan kepada nasabah untuk membeli barang dari pihak ketiga, akad murababah harus dilakukan setelah barang secara prinsip menjadi milik bank.

2) Adapun ketentuan murabahah kepada nasabah akan dijelaskan dibawah ini yaitu sebagai berikut:

a) Nasabah mengajukan permohonan dan janji pembelian suatu barang atau aset kepada bank.

10 Fatwa DSN MUI No.4 tahun 2000 Tentang Murabahah

Finansia Volume 02 Nomor 02 Juli-Desember 2019| 174 
b) Jika bank menerima permohonan tersebut, bank harus membeli barang atau aset yang dipesan nasabah secara sah kepada pedagang.

c) Bank kemudian menawarkan aset tersebut kepada nasabah dan nasabah harus menerima atau membelinya sesuai dengan janji yang telah disepakati, karena secara hukum janji tersebut mengikat, kemudian kedua belah pihak harus membuat kontrak jual beli.

d) Dalam jual beli ini bank dibolehkan meminta nasabah untuk membayar uang muka saat menandatangani kesepakatan awal pemesanan.

e) Jika nasabah kemudian menolak membeli barang tersebut, biaya riil bank harus dibayar dari uang muka tersebut.

f) Jika nilai uang muka kurang dari kerugian yang harusditanggung oleh bank, bank dapat meminta kembali sisakerugiannya kepada nasabah.

g) Jika uang muka memakai kontrak uang muka, maka:

(a) jika nasabah memutuskan untuk membeli barang tersebut, nasabah tinggal membayar sisa harga.

(b) jika nasabah batal membeli, uang muka menjadi milik bank maksimal sebesar kerugian yang ditanggung oleh bank akibat pembatalan tersebut, dan jika uang muka tidakmencukupi, nasabah wajib melunasi kekurangannya.

c. Standar Wakalah dalam Murabahah ${ }^{11}$ yaitu sebagai berikut :

1) Bank diperbolehkan memberi kuasa melalui akad wakalah kepada Nasabah untuk bertindak sebagai wakil Bank untuk membeli obyek Murabahah sesuai dengan spesifikasi, kondisi, serta harga yang telah disetujui oleh Bank.

2) Nasabah yang ditunjuk sebagai kuasa Bank berkewajiban memeriksaObyek Murabahah terhadap kualitas, kondisi, pemilihan dan spesifikasi Obyek Murabahah sesuai dengan yang telah disepakati.

3) Dalam pelaksanaan tugas Nasabah sebagai wakil Bank, Nasabah bertindak langsung untuk dan atas nama Bank dan mengambil langkahlangkah yang diperlukan untuk melindungi hak-hak dan kepentingan Bank dan tidak melakukan

11 Buku Standar Produk Murabahah, https://www.ojk.go.id/id/kanal/syariah/berita-dankegiatan/publikasi/Pages/Buku-Standar-Produk-Perbankan-Syariah-Murabahah.aspx 
atau melalaikan hal yang tidak sesuai dengan kewajiban dan tanggung jawab Nasabah.

4) Wakalah dalam transaksi Murabahah dapat meliputi namun tidak terbatas pada pemesanan obyek Murabahah, pembayaran sebagian atau keseluruhan harga obyek Murabahah dengan dana yang berasal dari Nasabah dan/atau Bank.

5) Dalam hal para pihak ingin melaksanakan akad pembiayaan Murabahah sebelum Nasabah melaksanakan tugas wakalahnya, maka akad Murabahah berlaku efektif setelah melakukan tugas wakalah (muallaq). Hal ini hanya bisa dilakukan ketika obyek Murabahah memerlukan waktu untuk mendapatkannya dan harus ditentukan jangka waktunya.

6) Nasabah yang bertindak sebagai wakalah pihak Bank tidak memiliki hak atau otoritas, baik secara tersirat maupun tersurat untuk:

a) membuat atau memberikan jaminan hutang, pernyataan atau jaminan (warranties) sehubungan dengan Pembelian atas nama Bank;

b) melaksanakan suatu kewajiban atau mengikat kontrak penjualan Barang atas nama Bank selain dari yang dinyatakan secara tegas dalam perjanjian atau akad; atau

c) meminta, menuntut, atau memperoleh penggantian biaya baik yangberkaitan dengan asuransi, upah, pergudangan, pengiriman atau hal-hal lainnya sehubungan dengan Barang selain dari yang ditetapkan dalam Harga Beli yang ditentukan.

7) Sebagai wakil, Nasabah akan bertanggung jawab untuk membeli dan melakukan penyerahan atas barang secara langsung dari penyedia pada tanggal penyerahan sebagaimana disebutkan dalam pemberitahuan transaksi yang telah disetujui oleh Bank.

8) Kepemilikan atas barang berpindah kepada Bank setelah penyerahan barang dari penyedia kepada Nasabah sebagai wakil Bank sesuai dengan cara yang telah ditetapkan dan disepakati lebih lanjut dalam perjanjian.

9) Nasabah menanggung semua risiko sehubungan dengan pencurian, kerugian, kerusakan dan musnahnya barang kecuali diakibatkan oleh hal-hal force majeur sejak tanggal penyerahan dari penyedia sampai dengan tanggal dimana Bank menyerahkannya kepada Nasabah. 
10) Nasabah dengan menggunakan biaya Nasabah sendiri dapat menutup asuransi atas Obyek Pembiayaan secara memadai, dimana Bank menjadi penerima utama pembayaran asuransi, yang meliputi risiko seperti kebakaran, kerugian, gempa bumi, pencurian, atau menutup asuransi lainnya yang diperlukan untuk mengasuransikan pemindahan, penyimpanan, dan pergudangan dari barang dengan nilai asuransi penuh, sesuai dengan ketentuan yang disyaratkan oleh Bank.

11) Nasabah tidak diperbolehkan mengadakan perubahan, pengesampingan, atau pembatalan terhadap pembelian, dan tidak ada ketentuan manapun yang dijadikan dasar bagi Nasabah untuk membatalkan pembelian tersebut tanpa persetujuan tertulis sebelumnya dari Bank.

12) Sepanjang seluruh syarat untuk pembayaran telah dipenuhi oleh nasabah dan tidak terjadi wanprestasi terhadap perjanjian pembiayaan, pembayaran harga beli akan dilakukan oleh Bank kepada Nasabah atau kepada penyedia.

Proses Pengajuan Pembiayaan Murabahah berdasarkan standar produk perbankan syariah yang dikeluarkan oleh OJK tahun 2016 ini sebagai salah satu upaya standarisasi produk perbankan syariah secara serial dilakukan oleh OJK bekerjasama dengan pelaku industri dan Dewan Syariah Nasional serta nara sumber lainnya ${ }^{12}$. Proses pengajuan pembiayaan murabahah dapat dilihat dari 4 tahapan yaitu tahap 1. pengajuan pembiayaan;tahap 2. verifikasi dokumen calon nasabah;tahap 3. persetujuan pengajuan pembiayaan dan tahap 4. pengikatan pembiayaan dan pengikatan jaminan.Berikut penjelasannya ${ }^{13}$ :

Pertama, Tahap I: Pengajuan Pembiayaan yaitu calon nasabah mengisi lengkap Formulir Aplikasi Permohonan Pembiayaan atau mengajukan Surat Permohonan Pembiayaan, kemudian menyerahkan dokumen-dokumen persyaratan lain yang diminta oleh Bank

Kedua,Tahap II: Verfikasi Dokumen Calon Nasabah yaitu (1) Pihak Bank akan melakukan verifikasi terhadap data diri Nasabah; (2) Pihak Bank akan melakukan analisa terhadap Profil Usaha Nasabah atau Profil Nasabah, Profabilitas Usaha, Analisa Arus Kas Usaha (dan/atau Arus Pendapatan Nasabah) dan Laporan Keuangan dan Melakukan Analisa Yuridis, (3) Pihak Bank akan melakukan penilaian jaminan yang diberikan Nasabah guna dijadikan pertimbangan dalam memberikan keputusan dan (4) Pihak Bank

$12 \quad$ Standar
https://www.ojk.go.id/id/kanal/syariah/berita-dan-kegiatan/publikasi/Pages/Buku-

13 Standar Produk Pembiayaan Murabahah ,.. h. 58 - 59 
akan membuat Usulan Pembiayaan berdasarkan analisa dan verifikasi terhadap dokumen Calon Nasabah.

Ketiga, Tahap III: Persetujuan Pengajuan Pembiayaan yaitu (1) Pihak Bank akan memberi keputusan perihal layak/tidaknya calon Nasabah diberikan pembiayaan, (2) Apabila Calon Nasabah dinyatakan layak, pihak Bank memberikan Surat Persetujuan Prinsip Pembiayaan kepada Calon Nasabah (Offering Letter), (3) Apabila Nasabah dinyatakan tidak layak, maka Pihak Bank akan segera mengkonfirmasi dan memberikan Surat Penolakan Pembiayaan kepada Nasabah.

Keempat,Tahap IV: Pengikatan Pembiayaan dan Pengikatan yaitu (1) Apabila Nasabah telah dinyatakan layak dan disetujui untuk diberikan pembiayaan, Nasabah diminta datang ke Bank untuk melakukan pengikatan, (2) Pihak Bank akan mengecek keaslian dokumen jaminan, (3) Nasabah akan melakukan pengikatan pembiayaan dan jaminan yang dilakukan dan dibuat oleh Notaris rekanan Bank, (4) Setelah pengikatan dilakukan, Bank menyimpan asli dokumen pengikatan pembiayaan dan jaminan, (5) Pengajuan Pembiayaan yang mengacu kepada prosedur umum pelaksanaan pembiayaan dan ketentuan lainnya yang ditetapkan oleh masing-masing Bank dan (6) Perhitungan plafond pembiayaan yaitu nominal plafond pembiayaan dari Bank ditentukan sesuai besar plafond yang layak diberikan kepada Nasabah. Nominal plafond pembiayaan untuk Nasabah ditentukan dari uang muka yang diberikan oleh Nasabah sendiri sebagai jaminan Nasabah akan melanjutkan transaksi Murabahah dengan Bank. ${ }^{14}$

\section{METODE PENELITIAN}

Jenis penelitian yang digunakan dalam penelitian ini adalah penelitian lapangan (field research). Penelitian lapangan yang dimaksud dalam penelitian ini adalah bahwa peneliti melakukan penelitian mengenai proses pengajuan pembiayaan murabahah yang berlokasi di Bank Syariah Rajasa Kantor Kas Kalirejo Lampung Tengah.

14Standar Produk Pembiayaan Murabahah , .. 
Penelitian ini bersifat deskriptif kualitatif. Artinya peneliti mendeskripsikan suatu obyek, fenomena, atau setting sosial yang akan dituangkan dalamtulisan yang bersifat naratif, ${ }^{15}$ yang bertujuan untuk mendapatkan informasi di Bank Syariah Rajasa mengenai proses pengajuan pembiayaan murababah ditinjau dari Standar Produk Murabahab yang dikeluarkan oleh OJK.

Sumber data primer dalam penelitian ini adalah Account Officer, Teller dan staf administrasi bagian pembiayaan di BPRS Rajasa Bandar Jaya Lampung Tengah, adapun sumber data sekundernya antara lain buku standar produk murabahab yang dikeluarkan oleh OJK tahun 2016 dan buku yang berjudul Akad dan Produk Bank Syariah karya Ascarya, Sistem dan proses pengajuan Bank Syariah karya Muhammad dan Bank Syariah dari Teori ke Praktik karya Muhammad Syafi'i Antonio.

Daam mengumpulkan data, peneitian melakukan wawancara dan jenis wawancaranya adalah jenis wawancara semi terstruktur. Maksudanya adaah dalam wawancara ini pewawancara tidak mengajukan persoalan berdasarkan daftar pertanyaan yang telah disiapkan ${ }^{16}$. Adapun yang peneliti wawancarai adalah Bapak Ahmad Khusaeri sebagai Account Officer, Ibu Listya Primadana selaku Teller dan Ibu Rini Septiani Indra, sebagai staf admin pembiayaan. Selain itu, peneliti menggunakan teknik dokumentasi sebagai pelengkap data dan informasi mengenai proses pengajuan pembiayaan murabahab di Bank Syariah Rajasa antara lain brosur, formulir-formulir pembiayaan, dan dokumen-dokumen pendukung lainnya.

Dalam penelitian ini, peneliti menggunakan teknik analisa data kualitatif dengan metode berpikir induktif. Teknik ini peneliti gunakan untuk menggali lebih dalam mengenai proses pengajuan pembiayaan murabahah ditinjau dari Standar Produk Murabahah.

\section{HASIL DAN PEMBAHASAN}

Bank Syariah Rajasa merupakan kantor kas dari BPRS Rajasa bandar jaya. Bank Syariah Rajasa didirikan 2 tahun setelah kantor pusat BPRS Rajasa Bandar Jaya didirikan, yaitu pada tanggal 28 juli 2010 sedangkan Kantor Pusat BPRS Rajasa didirikan pada tanggal 30 juli 2008. Awal berdiri Bank Syariah Rajasa yaitu berlokasi di Kaliwungu Lampung Tengah dan kemudian dua tahun setelahnya yaitu pada tahun 2015 Bank Syariah Rajasa

15 Albi Anggito dan Johan Setiawan, Metodologi Penelitian Kualitatif, (Suka Bumi: CV Jejak, 2018), h. 11

16 Albi Anggito \& Johan Setiawan, Metodologi Penelitian., h. 88 
dipindah lokasikan di jalan Jendral Soedirman Kalirejo Lampung Tengah dikarenakan semakin bertambahnya jumlah nasabah dan kurang luasnya kantor Bank Syariah Rajasa yang sebelumnya.$^{17}$ Adapun visi bank ini adalah terwujudnya bank syariah rajasa kalirejo lampung tengah yang profesional dan sehat sebagai mitra perekonomian umat menuju masyarakat madani.

Salah satu produk pembiayaan yang ada di bank Syariah Rajasa adalah Pembiayaan Murabahah yang menggunakan Akad Murabahah bil Wakalah dimana Bank memberi kuasa melalui akad wakalah kepada Nasabah untuk membeli obyek Murabahah sesuai dengan spesifikasi, kondisi, serta harga yang telah disetujui Bank. ${ }^{18}$

Transaksi muamalah ini menerapkan prinsip jual beli barang sebesar harga perolehan barang ditambah margin yang disepakati oleh para pihak. Harga perolehan diinformasikan oleh penjual kepada pembeli. Ketika terdapat pembiayaan Murabahah maka Pihak Bank Syariah Rajasa akan memberikan pembiayaan berupa Uang kepada nasabah Murabahah untuk membeli barang sesuai kebutuhan dan keinginan nasabah tersebut, ditambah dengan margin keuntungan dan diangsur sesuai kesepakatan antara pihak nasabah dan pihak Bank. ${ }^{19}$ Berikut jenis pembiayaan murabahah di Bank tersebut $:{ }^{20}$ Pertama, Pembiayaan murabahah Produktif, yaitu pembiayaan yang di tujukan untuk peningkatan usaha, baik usaha produksi, perdagangan, maupun investasi, misalnya seperti pembelian mesin produksi.

Kedua, Pembiayaan murabahah Konsumtif, yaitu pembiayaan yang di gunakan untuk memenuhi kebutuhan konsumsi, yang akan habis di gunakan untuk memenuhi kebutuhan, misalnya : Pembelian sepeda motor atau mobil

Adapun syarat - syarat yang harus disiapkan calon nasabah ketika mengajukan pebiayaan murabahah yaitu poto kopi KTP suami istri (jika sudah menikah), poto kopi KK, Poto kopi surat nikah, SKU (Surat Keterangan Usaha), rekening listrik, Pajak Bumi Bangunan (PBB) jika jaminan berupa sertifikat rumah atau tanah. ${ }^{21}$

Adapun proses pengajuan pembiayaan murabahah di Bank Syariah Rajasa adalah sebagai berikut :

\section{Pertama, Tahap I}

17http://www.bprsyariahrajasa.co.id/ di akses pada 27 juni 2019 , pukul 20.15

18Listya Primadana (Teller),Wawancara Pribadi, 15 Juli 2019

${ }^{19}$ Listya Primadana (Teller),...

${ }^{20}$ Listya Primadana (Teller),...

21 Brosur 
Calon nasabah yang akan mengajukan pembiayaan murabahah maka menemui Bapak Ahmad Khusaeri selaku Account Officer (AO) di Bank Syariah Rajasa dan disitu beliau akan menjelaskan mengenai produk murabahah antara lain menjelaskan mengenai plafond pinjaman yang diajukan nasabah dapat disetujui apabila sesuai dengan jaminan dan jenis usaha calon nasabah, kemudian AO juga menjelaskan bahwa angsuran dari plafond pinjaman dapat diangsur sesuai dengan jangka waktu yang diminta, semakin lama jangka waktu angsuran maka semakin kecil jumlah angsuran tiap bulannya, jika jangka waktu yang dipilih lebih singkat maka akan lebih besar angsuran pembiayaannya tiap bulan. Selain itu AO juga menjelaskan mengenai persyaratan-persyaratan pembiayaan murabahah. ${ }^{22}$ Nasabah akan dimintaipihak AO untuk mengisi formulir pembiayaan murabahah.

Calon nasabah menyerahkan persyaratan-persyaratan untuk mengajukan pembiayaan murabahah ke bank ${ }^{23}$ dan persyaratan yang harus dipenuhi calon nasabah dalam pembiayaan murabahah di Bank Syariah Rajasa, antara lain: ${ }^{24}$ Poto kopi E-KTP suami istri (jika sudah menikah),Poto kopi KK,Poto kopi surat nikah (jika sudah menikah),Poto kopi jaminan, misal BPKB atau sertifikat rumah atau tanah, SKU/Surat Keterangan Usaha dari kepala kampong, Rekening listrik, Jika jaminan berupa sertifikat rumah maka wajib melampirkan PBB, danjika jamirnan atas nama orang lain maka wajib melampirkan KTP pemilik jaminan dan melampirkan surat nikah jika si pemilik jaminan sudah menikah.

\title{
Kedua, Tahap II
}

Setelah calon nasabah mengajukan pembiayaan murabahah dengan mengisi formulir dan menyerahkan persyaratan-persyaratan pembiayaannya kepada Account Officer Bank Syariah Rajasa Kantor Kas Kalirejo maka Bank syariah Rajasa akan mengirimkan berkas pengajuan pembiayaan murabahah tersebut melalui via E-mail ke kantor pusat yaitu BPRS Rajasa Bandar Jaya Lampung Tengah untuk dilakukan pemeriksaan berkas pengajuan pembiayaan murabahah calon nasabah, dikantor pusat akan memeriksa apakah nasabah memiliki riwayat pinjaman dengan bank lain melalui BI Checking oleh Bapak Abdul Gani selaku Audit Internal. ${ }^{25}$ BI Checking digunakan untuk mengecek riwayat

\author{
22Ahmad Khusaeri (A0),Wawancara Pribadi, 6 Juli 2019 \\ ${ }^{23}$ Ahmad Khusaeri (AO),... \\ ${ }^{24}$ Ahmad Khusaeri (AO),... \\ 25Rini Septiani Indra (Admin Pembiayaan),Wawancara Pribadi, 12 Juli 2019
}


hutang calon nasabah yang mengajukan pembiayaan murabahah,untuk dilihat mengenai riwayat hutangnya tersebut termasuk golongan kredit macet atau lancar. Jika riwayat hutang calon nasabah termasuk kredit macet maka pembiayaan murabahah yang diajukan calon nasabah akan ditolak, apabila riwayat hutang calon nasabah termasuk kredit lancar maka akan diteruskan untuk melakukan pembiayaan murabahah. ${ }^{26}$

Setelah pemeriksaan BI Checking terhadap calon nasabah, maka dilakukan pemeriksaan kembali oleh kantor pusat mengenai jenis usaha, penghasilan, maupun jaminan apakah layak mendapatkan plafond pembiayaan yang diajukan calon nasabah, jika dinyatakan layak maka kantor pusat akan mengkonfirmasikan pada Bank Syariah Rajasa Kantor Kas Kalirejo bahwa calon nasabah disetujui untuk melakukan pembiayaan murabahah. ${ }^{27}$ Jadi kesimpulannya yaitu, setelah nasabah menyerahkan formulir yang telah diisi serta menyerahkan persyaratan-persyaratan yang diminta oleh pihak bank, kemudian pihak bank akan memeriksa apakah calon nasabah memiliki riwayat pinjaman dengan bank lain dan bagaimana kelancaran angsuran pembiayaannya dibank lain, jika calon nasabah memiliki riwayat kredit macet di bank lain maka permohonan pengajuan pembiayaan murabahah calon nasabah tersebut akan ditolak, dan jika tidak terdapat riwayat hutang di bank lain atau terdapat pembiayaan dengan bank lain tetapi riwayat kreditnya adalah lancar maka usulan calon nasabah untuk mengajukan pembiayaan murabahah akan diteruskan. $^{28}$

Kurang lebih 1(satu) minggu setelah dilakukan pengecekan kembali mengenai profil nasabah, plafond pinjaman dan jaminan oleh kantor pusat dan kemudian disetujui lalu kantor pusat menkonfirmasinya kepada Bank Syariah Rajasa Kantor Kas maka kemudian Pihak Bank Syariah Rajasa Kantor Kas Kalirejo yaitu Bapak Ahmad Khusaeri dan Bapak Nur Salim sebagai Account Officer/Marketing, akan melakukan survey untuk mengetahui kebenarannya secara langsung pada profil usaha calon nasabah untuk mengetahui pendapatan dari usaha calon nasabah apakah sekiranya mampu untuk membayar angsuran pembiayaan murabahah tersebut. ${ }^{29}$

Adapun yang dianalisa ketika survey yaitu usaha dari calon nasabah, keuntungan/margin dari usahanya dalam sebulan, kemudian dianalisa dengan biaya pengeluaran calon nasabah tersebut selama satu bulan termasuk dengan angsuran pembiayaan murabahah 
yang diajukan calon nasabah tersebut. Selain itu untuk melihat karakter calon nasabah, Bank Syariah Rajasa juga bertanya dengan orang-orang sekitar/tetangga calon nasabah mengenai bagaimana karakter calon nasabah tersebut apakah sering didatangi Debt Collector atau tidak, atau menanyakan sulit atau tidaknya calon nasabah tersebut dalam membayar hutang. ${ }^{30}$ Untuk lebih jelasnya, dibawah ini dijelaskan kelayakan usaha calon nasabah yang dinilai tim survey dari yaitu sebagai berikut: ${ }^{31}$

a. Tujuan nasabah mengajukan pembiayaan

Tim survey akan menanyakan kepada nasabah apa tujuan calon nasabah tersebut mengajukan pembiayaan murabahah, misalnya calon nasabah mengajukan pembiayaan murabahah untuk mendirikan bangunan, maka pihak bank akan menanyakan tujuan pendirian bangunan tersebut apakah untuk usaha atau untuk hal lainnya.

b. Usaha pokok/sampingan

Tim survey akan menilai apa usaha pokok maupun usaha sampingan calon nasabah, untuk dinilai pantas atau tidaknya usaha calon nasabah tersebut untuk mengajukan pembiayaan murabahah, karena usaha pokok calon nasabah harus usaha yang yang memungkinkan penghasilannya untuk mampu mengangsur pembiayaan murabahah.

c. Rata-rata pendapatan perbulan

Pihak bank akan mensurvey mengenai pendapatan perbulan calon nasabah, yaitu untuk mengetahui mengenai penghasilan calon nasabah dapat memenuhi kebutuhan sehari-harinya atau tidak, misalnya untuk biaya rumah tangga, biaya sekolah anak, biaya pribadi, maupun biaya angsuran pembiayaan murabahah untuk mengetahui apakah kondisi keuangan calon nasabah mampu untuk memenuhi kebutuhan tersebut, hal ini untuk menilai kemampuan mengangsur angsuran pembiayaan murabahah calon nasabah.

d. Perkembangan usaha yang dijalankan

Pihak bank akan menilai calon nasabah layak atau tidak untuk mengajukan pembiayaan murabahah dengan mengetahui perkembangan usaha yang dijalankan oleh calon nasabah, karena jika usaha calon nasabah memiliki perkembangan yang baik maka hal tersebut dapat meyakinkan pihak Bank untuk memberikan pembiayaan murabahah. 
e. Nilai jaminan

Penilaian mengenai jaminan dapat dilihat dari jumlah pinjamannya, untuk pinjaman berkisar 10-15 juta maka dapat menggunakan jaminan berupa SHM (Sertifikat Hak Milik) atau BPKB (Buku Pemilik Kendaraan Bermotor), jika jaminan merupakan SHM maka tim survey akan menilai jenis jaminannya jika berupa perumahan atau pekarangan maka perumahan atau pekarangan tersebut di cek kondisinya apakah bangunannya atau pekarangannya masih kokoh dan terawat untuk menilai harga jualnya.Jaminan berupa BPKB mobil maka dilihat dari tahun pembelian, jika pembelian diatas tahun 2010 maka pembiayaanya bisa diatas 50 juta rupiah karena pembiayaan murabahah hanya dapat 50\% dari harga jual jaminan.Jika pembiayaan dibawah 15 juta maka jaminan dapat berupa AJB (Akta Jual Beli) atau bisa juga dengan jaminan BPKB motor yang pajaknya masih hidup, karena jika jaminan BPKB motor tidak hidup maka tidak bisa mengajukan pembiayaan murabahah di Bank Syariah Rajasa.

f. Sikap dan perilaku pemohon saat mengajukan permohonan

Pihak Bank akan menilai sikap dan perilaku calon nasabah pada saat mengajukan pembiayaan, karena sikap dan perilaku dari calon nasabah dapat menentukan disetujui atau tidaknya pembiayaan murabahah di Bank Syariah Rajasa.

\section{Ketiga, Tahap III}

Setelah seminggu dilakukannya survey kemudian pihak bank akan mengusulkan apakah calon nasabah diterima untuk mengajukan pembiayaan atau tidak dilihat dari analisa yang telah pihak bank baik dari Kantor Pusat BPRS Rajasa Bandar Jaya maupun Bank Syariah Rajasa Kantor Kas Kalirejo lakukan tersebut. Untuk diterima atau ditolaknya pengajuan pembiayaan Murabahah maka nasabah akan diinformasikan melalui telepon. ${ }^{32}$

\section{Keempat, Tahap IV}

Calon nasabah diminta untuk datang ke Bank Syariah rajasa melalui telepon untuk melakukan akad dan penyerahan uang untuk nasabah yang mendapatkan pembiayaan Murabahah. untuk pengikatan pembiayaan dan jaminan yang dilakukan oleh notaris

32Listya Primadana (Teller),Wawancara Pribadi, 9 Juli 2019 
kemudian Setelah melakukan akad bank akan meyimpan dokumen jaminan nasabah dan akan dikembalikan setelah angsuran pembiayaan murabahah telah lunas. ${ }^{33}$

Berdasarkan hasil temuan di lapangan maka dapat disimpulkan bahwa proses pengajuan pembiayaan Murabahah di Bank Syariah Rajasa kantor Kas Kalirejo melalui empat tahap sebagaimana yang ditetapkan oleh OJK. Dalam proses pengajuan pembiayaan murabahah di Bank Rajasa Kantor Kas Kalirejo ini melalui empat tahap yaitu :

Pertama, tahap I (tahap pengajuan pembiayaan) dijelaskan bahwa calon nasabah mengisi lengkap formulir aplikasi permohonan pembiayaan atau mengajukan surat permohonan pembiayaan, kemudian yang kedua calon nasabah menyerahkan dokumen-dokumen persyaratan lain yang diminta oleh Bank, dalam teori ini telah sesuai dengan proses yang dilakukan di Bank Syariah Rajasa bahwa pada pengajuan pembiayaan murabahah tahap I yaitu, Calon nasabah akan diminta oleh Bapak Ahmad Khusaeri sebagai Account Officer (AO) di Bank Syariah Rajasa untuk mengisi formulir pembiayaan murabahah, dan memberikan Persyaratan-persyaratan yang harus dipenuhi calon nasabah dalam pembiayaan murabahah.

Kedua, tahap II dimana berdasarkan standar produk perbankan syariah pembiayaan murabahah yang dikeluarkan OJK tahun 2016,maka tahap kedua juga sesuai dnegan tahap yang ditetapkan OJK. Pada tahap II ini pihak bank akan melakukan verifikasi terhadap data diri nasabah, kemudian pihak bank akan melakukan analisa terhadap profil usaha nasabah dan profil nasabah, profabilitas usaha, analisa arus kas usaha (dan/atau arus pendapatan nasabah) dan laporan keuangan, kemudian pihak bank akan melakukan penilaian jaminan yang diberikan nasabah guna dijadikan pertimbangan dalam memberikan keputusan, lalu pihak bank akan membuat usulan pembiayaan berdasarkan analisa dan verifikasi terhadap dokumen calon nasabah, hal tersebut sesuai dengan pelaksanaan di Bank Syariah Rajasa kantor Kas Kalirejo yaitu Bank syariah Rajasa akan mengirimkan berkas pengajuan pembiayaan murabahah tersebut melalui via E-mail ke kantor pusat yaitu BPRS Rajasa Bandar Jaya Lampung Tengah untuk dilakukan pemeriksaan berkas pengajuan dan jaminan pembiayaan murabahah, dikantor pusat akan memeriksa apakah calon nasabah memiliki riwayat pinjaman dengan bank lain melalui BI Checking oleh Bapak Abdul Gani selaku Audit Internal, setelah dilakukan pemeriksaan oleh kantor pusat kemudian Pihak Bank Syariah Rajasa Kantor Kas Kalirejo yaitu Bapak 
Ahmad Khusaeri dan Bapak Nur Salim sebagai Marketing/Account Officer akan melakukan survey untuk mengetahui kebenarannya secara langsung pada profil usaha calon nasabah dalam mengetahui pendapatan dari usaha calon nasabah apakah sekiranya mampu untuk membayar angsuran pembiayaan murabahah yang diajukan calon nasabah tersebut hal ini bertujuan untuk membuat usulan diterima atau ditolaknya pengajuan pembiayaan murabahah yang diajukan oleh nasabah.

Ketiga, pada tahap ke III ada satu perbedaan antara standar yang ditetapkan OJK dengan tahap yang dilaksanakan oleh Bank Rajasa Kalirejo, yaitu pada persetujuan pembiayaan murabahah.Dijelaskan dalam standar produk perbankan syariah pembiayaan murabahah yang dikeluarkan OJK pada tahun 2016 yaitu apabila calon nasabah dinyatakan layak, maka pihak bank memberikan surat persetujuan prinsip (Offering Letter) dan apabila nasabah dinyatakan tidak layak, maka pihak bank akan segera mengkonfirmasi dan memberikan surat penolakan pembiayaan kepada nasabah.Pada tahap ketiga ini, Bank Rajasa Kantor Kas Kalirejo, hanya mengkonfirmasikan nasabah melalui telepon untuk menjelaskan bahwa si calon nasabah diterima atau ditolaknya pengajuan pembiayaan murabahah. Maka pada tahap ketiga, ada ketidaksesuaian dnegan standar dari OJK yaitu pada pemberitahuan. Jika OJK meminta bank mengirimkan suarat persetujuan prinsip ayau offering letter maka bank Rajasa Kantor Kas Kalirejo melakukan pemberitahuan melalui telepon

Keempat, tahap IV mengenai pengikatan pemiayaan dan pengikatan jaminan dalam standar produk pembiayaan murabahah dijelaskan bahwa apabila calon nasabah telah dinyatakan layak dan disetujui untuk diberikan pembiayaan, maka si calon nasabah diminta datang ke Bank untuk melakukan pengikatan dan Pihak Bank akan mengecek keaslian dokumen jaminan, kemudian si calon nasabah akan melakukan pengikatan pembiayaan dan jaminan yang dilakukan dan dibuat oleh Notaris rekanan Bank.Setelah itu Bank akan menyimpan asli dokumen pengikatan pembiayaan dan jaminan. Pada tahap IV ini telah dipraktikkan pada Bank Syariah Rajasa yaitu apabila calon nasabah dinyatakan layak untuk mengajukan pembiayaan Murabahah maka calon nasabah diminta untuk datang ke Bank Syariah rajasa untuk melakukan akad dan penyerahan uang untuk nasabah yang mendapatkan pembiayaan Murabahah. untuk pengikatan pembiayaan dan jaminan yang dilakukan oleh notaris. Maka tahap keempat ini sesuai dengan standar dari OJK.

Ada satu tahap yang kurang sesuai yaitu pada tahap ketiga dimana seharusnya Bank Rajasa Kantor Kas Kalirejo membuat offering letter ke calon nasabah, tetapi pihka bank 
hanya melakukan pemberitahuan persetujuan atau penolakan pengajuan pembiayaan melalui telepon. Adapun tahap - tahap yang lainnya telah sesuai dengan standar produk perbankan syariah murabahah yang dikeluarkan oleh Deputi Komisioner Pengawas Perbankan I tahun 2016. Berikut hasil kesimpulan penelitian ini :

Tabel 1 : Kesimpulan

\begin{tabular}{|c|c|c|c|}
\hline $\begin{array}{l}\text { Tahap } \\
\text { ke - }\end{array}$ & $\begin{array}{c}\text { Standar Produk Perbankan Syariah } \\
\text { Murabahah (OJK) }\end{array}$ & Hasil lapangan & Keterangan \\
\hline 1 & $\begin{array}{l}\text { Pengajuan Pembiayaan: } \\
\text { a. calon nasabah mengisi lengkap } \\
\text { Formulir Aplikasi } \\
\text { Permohonan Pembiayaan atau } \\
\text { mengajukan Surat } \\
\text { Permohonan Pembiayaan, } \\
\text { b. Penyerahan dokumen- } \\
\text { dokumen persyaratan lain yang } \\
\text { diminta oleh Bank }\end{array}$ & $\begin{array}{l}\text { Pengajuan pembiayaan: } \\
\text { a. Calon nasabah mengajukan } \\
\text { pembiayaan murabahah ke } \\
\text { Ahmad Khusaeri selaku Account } \\
\text { Officer (AO) di Bank Syariah } \\
\text { Rajasa dengan menjelaskan antara } \\
\text { lain : } \\
\text { 1) plafond pinjaman yang } \\
\text { diajukan nasabah } \\
\text { 2) jaminan } \\
\text { 3) jenis usaha dari plafond } \\
\text { 4) angsuran diangsur } \\
\text { pinjaman dapat den jangka waktu } \\
\text { sesuai dengan janga } \\
\text { yang diminta } \\
\text { b. Calon nasabah mengisi formuir } \\
\text { c. Caon nasabah menyerahkan } \\
\text { persyaratan-persyaratan } \\
\text { pengajuan pembiayaan } \\
\text { murabahah dan dokumen- } \\
\text { dokumennya seperti : } \\
\text { 1) Poto kopi E-KTP suami } \\
\text { istri (jika sudah menikah) } \\
\text { 2) Poto kopi KK } \\
\text { 3) Poto kopi surat nikah (jika } \\
\text { sudah menikah) } \\
\text { 4) Poto kopi jaminan, misal } \\
\text { BPKB atau sertifikat rumah } \\
\text { atau tanah } \\
\text { 5) SKU/Surat Keterangan } \\
\text { Usaha dari kepala kampong } \\
\text { 6) Rekening listrik } \\
\text { 7) Jika jaminan berupa sertifikat } \\
\text { rumah maka wajib } \\
\text { melampirkan PBB, dan Jika } \\
\text { jamirnan atas nama orang } \\
\text { lain maka wajib melampirkan } \\
\text { KTP pemilik jaminan dan } \\
\text { melampirkan surat nikah jika } \\
\text { si pemilik jaminan sudah } \\
\text { menikah. }\end{array}$ & $\begin{array}{l}\text { Sesuai } \\
\text { dengan } \\
\text { Standar } \\
\text { Produk } \\
\text { Perbankan } \\
\text { Syariah } \\
\text { Murabahah } \\
\text { (OJK) }\end{array}$ \\
\hline
\end{tabular}




\begin{tabular}{|c|c|c|c|}
\hline & & & \\
\hline 2 & $\begin{array}{l}\text { Verfikasi Dokumen Calon } \\
\text { Nasabah: } \\
\text { a. Pihak Bank akan melakukan } \\
\text { verifikasi terhadap data diri } \\
\text { Nasabah } \\
\text { b. Pihak Bank akan melakukan } \\
\text { analisa terhadap Profil Usaha } \\
\text { Nasabah atau Profil Nasabah, } \\
\text { Profabilitas Usaha, Analisa } \\
\text { Arus Kas Usaha (dan/atau } \\
\text { Arus Pendapatan Nasabah) dan } \\
\text { Laporan Keuangan dan } \\
\text { Melakukan Analisa Yuridis } \\
\text { c. Pihak Bank akan melakukan } \\
\text { penilaian jaminan yang } \\
\text { diberikan Nasabah guna } \\
\text { dijadikan pertimbangan dalam } \\
\text { memberikan keputusan } \\
\text { d. Pihak Bank akan membuat } \\
\text { Usulan Pembiayaan } \\
\text { berdasarkan analisa dan } \\
\text { verifikasi terhadap dokumen } \\
\text { Calon Nasabah. }\end{array}$ & 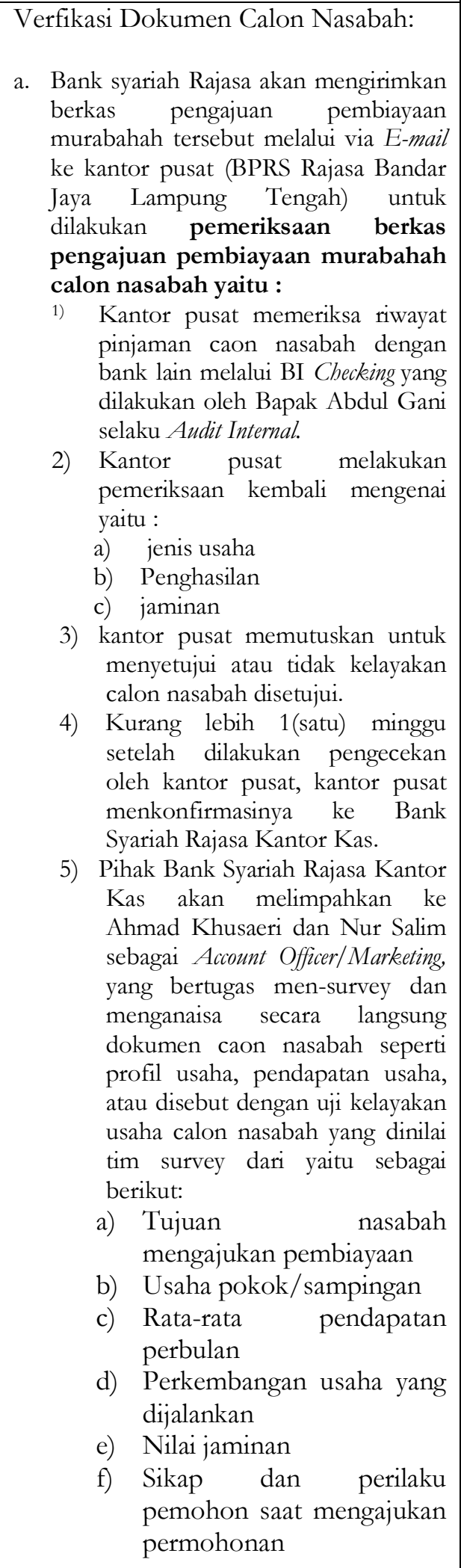 & $\begin{array}{l}\text { Sesuai } \\
\text { dengan } \\
\text { Standar } \\
\text { Produk } \\
\text { Perbankan } \\
\text { Syariah } \\
\text { Murabahah } \\
\text { (OJK) }\end{array}$ \\
\hline 3 & Persetujuan Pengajuan Pembiayaan & $\begin{array}{l}\text { Persetujuan Pengajuan Pembiayaan: } \\
\text { a. Setelah seminggu survey, bank }\end{array}$ & $\begin{array}{l}\text { Tidak sesuai } \\
\text { dengan } \\
\text { Standar }\end{array}$ \\
\hline
\end{tabular}




\begin{tabular}{|c|c|c|c|}
\hline & $\begin{array}{l}\text { a. } \begin{array}{l}\text { Pihak Bank akan memberi } \\
\text { keputusan perihal }\end{array} \\
\text { layak/tidaknya calon Nasabah } \\
\text { diberikan pembiayaan } \\
\text { b. Apabila Calon Nasabah } \\
\text { dinyatakan layak, pihak Bank } \\
\text { memberikan Surat } \\
\text { Persetujuan Prinsip } \\
\text { Pembiayaan kepada Calon } \\
\text { Nasabah (Offering Letter) } \\
\text { c. Apabila Nasabah dinyatakan } \\
\text { tidak layak, maka Pihak Bank } \\
\text { akan segera mengkonfirmasi } \\
\text { dan memberikan Surat } \\
\text { Penolakan Pembiayaan kepada } \\
\text { Nasabah. }\end{array}$ & $\begin{array}{l}\text { akan mengusulkan apakah calon } \\
\text { nasabah diterima atau tidak. } \\
\text { b. Untuk diterima atau ditolaknya } \\
\text { pengajuan pembiayaan Murabahah } \\
\text { maka nasabah akan diinformasikan } \\
\text { melalui telepon. }\end{array}$ & $\begin{array}{l}\text { Produk } \\
\text { Perbankan } \\
\text { Syariah } \\
\text { Murabahah } \\
\text { (OJK) }\end{array}$ \\
\hline 4 & 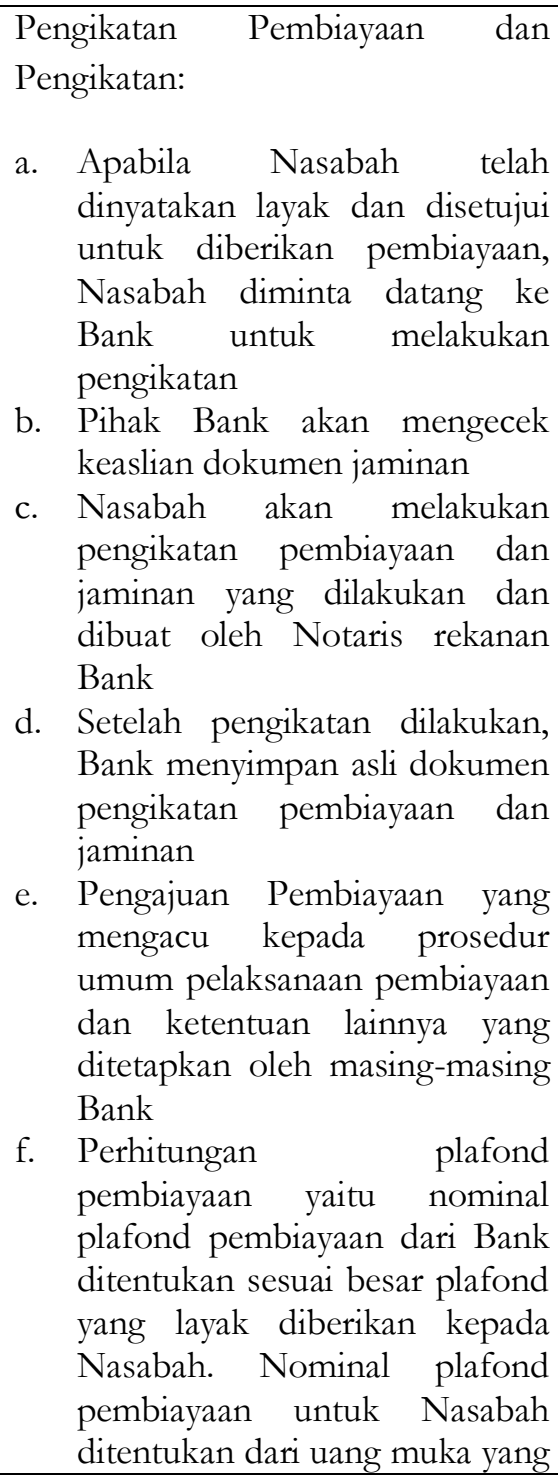 & $\begin{array}{l}\text { Pengikatan Pembiayaan dan } \\
\text { Pengikatan: } \\
\text { a. Apabila calon nasabah dinyatakan } \\
\text { layak untuk mengajukan pembiayaan } \\
\text { Murabahah maka calon nasabah } \\
\text { diminta untuk datang ke Bank } \\
\text { Syariah rajasa melalui telepon untuk } \\
\text { melakukan akad dan penyerahan } \\
\text { uang untuk nasabah yang } \\
\text { mendapatkan pembiayaan } \\
\text { Murabahah. } \\
\text { b. Pengikatan pembiayaan dan jaminan } \\
\text { dilakukan oleh notaris an akan } \\
\text { c. Setelah melakukan akad, bank akan } \\
\text { meyimpan dokumen jaminan } \\
\text { nasabah dan akan dikembalikan } \\
\text { setelah angsuran pembiayaan } \\
\text { murabahah telah lunas }\end{array}$ & $\begin{array}{l}\text { Sesuai } \\
\text { dengan } \\
\text { Standar } \\
\text { Produk } \\
\text { Perbankan } \\
\text { Syariah } \\
\text { Murabahah } \\
\text { (OJK) }\end{array}$ \\
\hline
\end{tabular}




\begin{tabular}{|l|l|l|l|}
\hline & $\begin{array}{l}\text { diberikan oleh Nasabah sendiri } \\
\text { sebagai jaminan Nasabah akan } \\
\text { melanjutkan transaksi } \\
\text { Murababah dengan Bank. }\end{array}$ & & \\
\hline
\end{tabular}

\section{E. Kesimpulan}

Proses pengajuan pembiayaan murabahah yang dilaksanakan oleh Bank Syariah Rajasa Kantor Kas Kalirejo melalui empat tahap pengajuan pembiayaan murabahah yaitu Tahap I (pengajuan pembiayaan), Tahap II (verifikasi dokumen calon nasabah), tahap III ( persetujuan pengajuan pembiayaan) dan Tahap IV (pengikatan pembiayaan dan pengikatan jaminan), akan tetapi dalam tahap III ( persetujuan pengajuan pembiayaan) terdapat kesenjangan antara standar produk perbankan syariah murabahah yang dikeluarkan OJK tahun 2016 dengan penerapan di Bank Syariah Rajasa kantor Kas Kalirejo. Pada tahap ketiga ini pihak Bank Syariah hanya mengkonfirmasikan nasabah melalui telepon mengenai diterima atau ditolaknya pembiayaan murabahah yang nasabah ajukan akan tetapi pada standar produk perbankan murabahah (OJK) dijelaskan bahwa pihak bank memberikan surat persetujuan prinsip (Offering Letter) dan apabila nasabah dinyatakan tidak layak, maka pihak bank akan segera mengkonfirmasi dan memberikan surat penolakan pembiayaan kepada nasabah.

\section{F. DAFTAR PUSTAKA}

Abdurrahmat Fathoni, Metodologi Penelitian dan Penyusunan Skripsi, (Jakarta: Rineka Cipta, 2011), h.96 Albi Anggito dan Johan Setiawan, Metodologi Penelitian Kualitatif, (Suka Bumi: CV Jejak, 2018), h. 11 Beni Ahmad Saebani, Metodologi Penelitian, (Bandung: CV Pustaka Setia, 2008), h. 190

Muhammad, Sistem dan Prosedur Operasional Bank Syariah, (Yogyakarta: UII Press, 2008), h. 103

Sugiyono, Metode Penelitian Kuantitatif, Kualitatif, dan R\&D, (Bandung: Alfabeta CV, 2016), h. 137

Fatwa DSN-MUI No: 111/DSN-MUI/IX/2017 Tentang Akad Jual Beli Murabahah

OJK, Standar Produk Pembiayaan Murabahah, https://www.ojk.go.id/id/kanal/syariah/berita-dankegiatan/publikasi/Pages/Buku-Standar-Produk-Perbankan-Syariah-Murabahah.aspx

Peraturan Bank Indonesia (PBI) Nomor: 7/46/PBI/2005 Tentang Akad Penghimpunan dan Penyaluran Dana Bagi Bank yang Melaksanakan Kegiatan Usaha Berdasarkan Prinsip Syariah 